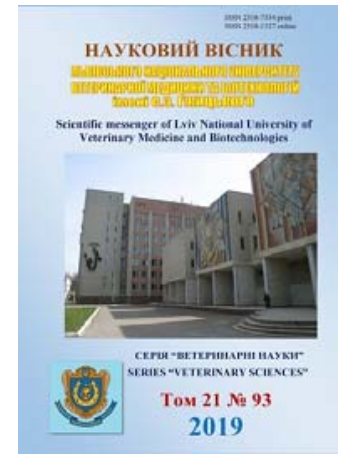

Науковий вісник Дьвівського національного університету ветеринарної медицини та біотехнологій імені С.3. Гжицького.

\author{
Серія: Ветеринарні науки
}

Scientific Messenger of Lviv National University of Veterinary Medicine and Biotechnologies. Series: Veterinary sciences

UDC 619:98:614.4:636.5

\title{
Investigation of corrosion activity and foaming properties of biocide "DezSan"
}

\author{
O.L. Nechyporenko, A.V. Berezovskyy, T.I. Fotina, R.V. Petrov
}

Sumy National Agrarian University, Sumy, Ukraine

\section{Article info}

Received 25.01.2019 Received in revised form 12.03.2019

Accepted 13.03.2019

Sumy National Agrarian University, G. Kondrat'eva Str., 160, Sumy, 40000, Ukraine. Tel.: +38-095-495-29-33 E-mail: tif_ua@meta.ua

Nechyporenko, O.L., Berezovskyy, A.V., Fotina, T.I., \& Petrov, R.V. (2019). Investigation of corrosion activity and foaming properties of biocide "DezSan". Scientific Messenger of Lviv National University of Veterinary Medicine and Biotechnologies. Series: Veterinary sciences, 21(93), 88-92. doi: $10.32718 /$ nvlvet 9315

The article presents data on the study of corrosion activity and foaming properties of biocide "DezSan". One of the main characteristics of a biocide is its corrosive activity. The use of a biocide in a poultry house involves getting it on metal, rubber, plastic surfaces, and the like. The biocide should provide minimal aggressive effect on the surface data. In the industrial poultry industry, the most frequently used equipment with surfaces made of stainless steel, aluminum and galvanized iron. Also, when choosing a biocide, pay attention to its foaming properties. They should not exceed $40 \%$, as this ensures a quality disinfection. One of the key points is the index of foam stability, which significantly affects the time of contact with the biocide and provides effective decontamination of the surfaces. The goal of the work. To determine the corrosion activity and foaming properties of the new domestic biocide "DezSan". Materials and methods of research. In their experiments, a disinfection tool for the production of the scientific and production company "Brovafarma" (Ukraine) "DesSan" was used. Relative corrosion activity of various concentrations of biocide "DezSan" was determined in comparison with the standard - 1.5\% solution of sodium hydroxide. To determine the foaming properties of biocide "DezSan" used the method of Ross-Miles (1983). Results of research and discussion. The biocide "DezSan" in all experimented concentrations (0.25-1.5\%) has a minor corrosion effect on aluminum, stainless and galvanized steel, compared with the standard (1.5\% NaOH solution). The biocide "DezSan" does not cause deformation when exposed to metal samples. "DezSan" in various concentrations has a foaming property of 13.1 to $37.3 \%$, which increased directly in proportion to increasing the concentration of biocides. The foaming capacity of "DezSan" did not exceed $40 \%$, and the foam stability at these concentrations varied within 0,08-0,19. Conclusions and prospects for further research. Thus, the biocide "DezSan" has low corrosion properties in relation to aluminum, stainless steel and galvanized steel in comparison with the standard (1.5\% solution of NaOH). The biocide "DezSan" does not cause deformation when exposed to metal samples. The foaming capacity was not more than $40 \%$, and the foam resistance was up to 0.19. These indicators allow the wide use of biocide "DezSan" in the poultry industry. In the future, it is planned to conduct a study of the biocid "DezSan", identified it irritating, skin-resorptive, cumulative and other properties.

Key words: disinfection, well-being, poultry farming, corrosive properties, foaming properties, biocid "DezSan".

\section{Дослідження корозійної активності та піноутворюючих властивостей біоциду “ДезСан”}

\author{
О.Л. Нечипоренко, А.В. Березовський, Т.І. Фотіна, Р.В. Петров
}

Сумський національний аграрний університет, м. Суми, Украӥна

В статті наведені дані щзодо дослідження корозійної активності та піноутворюючих властивостей біоциду “ДезСан”. Однією з основних характеристик дезінфікуючого засобу є його корозійна активність. Застосування дезінфекиійного препарату у 
пташнику передбачає потрапляння його на металеві, гумові, пластикові поверхні, тошо. Дезінфікуючий препарат повинен забезпечувати мінімальний агресивний вплив на дані поверхні. В умовах промислового птахівництва найбільи часто використовують обладнання з поверхнями виготовленими з нержавіючої сталі, алюмінію та очинкованого заліза. Також при виборі дезінфектанту звертають увагу на його піноутворюючі властивості. Вони не повинні перевишувати 40\%, так як це забезпечує проведення якісної дезінфекиії. Одним із ключових моментів є показник стійкості піни, що суттєво впливає на час контакту з дезінфектантом $і$ забезпечує ефективне знезараження поверхонь. В зв'язку з изим метою наших досліджень було визначити корозійну активність та піноутворюючі властивості нового вітчизняного біочиду “ДезСан”. В свої дослідах використовували дезінфекційний засіб виробництва науково-виробничої фірми “Бровафарма” (Україна) “ДезСан”. Відносну корозійну активність різних концентрацій дезінфікуючої речовини “ДезСан” визначали у порівнянні з еталоном - 1,5\% розчином натру ідкого. Для визначення піноутворюючих властивостей дезінфектанту “ДезСан” використовували метод Росс-Майлса (1983). Біоцид “ДезСан” в усіх взятих для досліду концентраціях (0,25-1,5\%) чинить незначну корозійну дію на алюміній, нержавіючу та оцинковану сталь, в порівнянні з еталоном (1,5\% розчином NaOH). Дезінфікуючий засіб “ДезСан” при потраплянні на зразки металів не викликає їх деформацію. “ДезСан” в різних кониентраціях має піноутворюючу властивість від 13,1 до 37,3\%, яка підвищувалася прямо пропориійно до збільшення концентрації деззасобу. Піноутворююча здатність “ДезСан” не перевищувала 40\%, а стійкість піни за изих концентрацій змінювалась в межах 0,08-0,19. Таким чином, біочид “ДезСан” має низькі корозійні властивості шьодо алюмінію, неіржавіючої сталі та очинкованої сталі в порівнянні з еталоном (1,5\% розчином NaОН). Дезінфікуючий засіб “ДезСан” при потраплянні на зразки металів не викликає їх деформацію. Піноутворююча здатність була не більше 40\%, а стійкість піни була до 0,19. Дані показники дозволяють широко використовувати біоцид “ДезСан” в птахівничій галузі.

Ключові слова: дезінфекція, благополуччя, птахівництво, корозійні властивості, піноутворюючі властивості, біочид “ДезСан”.

\section{Вступ}

Для профілактики виникнення інфекційних захворювань серед поголів'я на птахофабриках використовують комплекс заходів, ключовим 3 яких є проведення дезінфекції інкубаторів, приміщень, обладнання, інвентарю, тощо. Дезінфекцію в пташниках обов'язково проводять 3 урахуванням стійкості збудників захворювання до фізико-хімічних факторів дезінфікуючого засобу та можливої небезпеки для оточуючого середовища (Berezovskyi et al., 2007; Nechyporenko et al., 2018). Основне призначення дезінфекційної обробки - розірвання епізоотичного ланцюгу інфекцій шляхом впливу на іiі найважливішу ланку - фактор передачі збудника хвороби від джерел інфекції до сприйнятливого організму (Zavhorodnii et al., 2013; Tishyn et al., 2017).

Актуальність теми. На сьогоднішній день в птахівництві використовують широкий спектр дезінфекційних препаратів. Препарати, що призначені для використання в різних напрямках, мають відмінні один від одного характеристики антимікробної ефективності (Berezovskyi et al., 2007; Palii \& Zavhorodnii, 2011).

При виборі дезінфікуючого засобу до нього пред'являють ряд вимог, що включає спектр антимікробної дії; корозійну активність; безпечність для персоналу й птиці; можливість розчинення у воді або утворення стійких емульсій; відсутність різкого запаху дезінфектанту; відсутність фарбування та забруднення об'єкта дезінфекції; стійкість дезінфікуючого препарату при зберіганні, використанні, транспортуванні; висока проникна здатність; екологічна безпечність та вартість дезінфектанту. Пріоритет повинен віддаватися дезінфікуючим препаратам вітчизняного виробництва (Berezovskyi et al., 2007; Zavhorodnii et al., 2013; Instruktsiia $\mathrm{z}$ provedennia sanitarnoi obrobky..., 2016).

Однією з основних характеристик дезінфікуючого засобу $\epsilon$ його корозійна активність. Застосування дезінфекційного препарату у пташнику передбачає потрапляння його на металеві, гумові, пластикові поверхні, тощо. Дезінфікуючий препарат повинен забезпечувати мінімальний агресивний вплив на дані поверхні. В умовах промислового птахівництва найбільш часто використовують обладнання 3 поверхнями виготовленими з нержавіючої сталі, алюмінію та оцинкованого заліза. Використання дезінфікуючого засобу з підвищеним агресивним впливом на зазначені матеріали призведе до порушення його структури, накопичення на ньому мікроорганізмів, що, в свою чергу, призведе до погіршення якості дезінфекції (Instruktsiia z provedennia sanitarnoi obrobky..., 2016).

Також при виборі дезінфектанту звертають увагу на його піноутворюючі властивості. Вони не повинні перевищувати $40 \%$, так як це забезпечує проведення якісної дезінфекції. Одним із ключових моментів $\epsilon$ показник стійкості піни, що суттєво впливає на час контакту з дезінфектантом і забезпечує ефективне знезараження поверхонь (Benson et al., 2007).

Мета $і$ завдання дослідження. В зв'язку з цим метою досліджень було визначити корозійну активність та піноутворюючі властивості нового вітчизняного біоціду “ДезСан”. Для досягнення поставленої мети необхідно було вирішити наступні задачі:

1. Встановити корозійні властивості “ДезСан" щодо неіржавіючої сталі, алюмінію та оцинкованої сталі в порівнянні з розчином гідроксиду натрію.

2. Дослідити піноутворюючі властивості засобу “ДезСан”.

3. Надати пропозиції з урахуванням отриманих результатів про перспективи використання засобу “ДезСан” в птахівництві.

\section{Матеріал і методи досліджень}

Робота виконувалася на базі лабораторії “Інноваційні технології та безпеки і якості продуктів тваринництва" та "Ветеринарна фармація" кафедри ветсанекспертизи, мікробіології, зоогігієни та безпеки і якості продуктів тваринництва факультету ветеринарної медицини Сумського національного аграрного університету. 
В дослідах використовували біоцид виробництва науково-виробничої фірми "Бровафарма" (Україна) “ДезСан”, що містить: алкілдиметилбензиламонію хлорид; октилдецилдиметиламонію хлорид; диоктилдиметиламонію хлорид; дидецилдиметиламонію хлорид; глутаровий альдегід. Розчин має бактерицидну та спороцидну дію на більшість грампозитивних і грамнегативних бактерій, включаючи патогенних збудників Mycobacterium spp., Yersinia enterocolitica тощо; віруцидну дію на РНК-вмісні віруси Avibirnavirus, Paramixovirus, Orthomixovirus, ДНК-вмісні віруси Parvovirus, Dependovirus, Aviadenovirus, Avipoxvirus, Circovirus; фунгіцидну дію на гриби Aspergillus spp., Penicbllium spp., Candida spp., Trichophyton spp., Microsporum spp.

Відносну корозійну активність різних концентрацій дезінфікуючої речовини “ДезСан” визначали у порівнянні з еталоном - 1,5\% розчином натру їдкого (Metodika opredelenija i ocenki korrozionnoj aktivnosti..., 1974).

Для визначення піноутворюючих властивостей дезінфектанту “ДезСан” використовували метод Росс-
Майлса (1983). Відношенням об'єму піни до об’єму рідини визначали кратність піни у відсотках.

Дослідження стабільності піни проводили шляхом визначення зменшення стовпчику піни, що знижується за 10 хвилин, згідно формули:

$$
y=\frac{H_{10}}{H_{0}},
$$

де, $\dot{I}_{0}$ - висота піни перед проведенням досліду;

$\dot{I}_{10}-$ зменшення піни протягом 10 хв проведення досліду.

\section{Результати та їх обговорення}

Результати досліджень корозійної активності біоциду “ДезСан” щодо алюмінію, неіржавіючої сталі наведені в таблиці 1.

Були проведенні дослідження по виявленню корозійної активності біоциду відносно оцинкованої сталі, так як цей матеріал широко застосовується в при будівництві птахівничих приміщень.

Результати досліджень корозійної активності біоциду “ДезСан” щодо оцинкованої сталі наведені в таблиці 2.

\section{Таблиця 1}

Ступінь корозійної дії біоциду “ДезСан” на алюміній та неіржавіючу сталь $(\mathrm{M} \pm \mathrm{m}) \mathrm{n}=10$

\begin{tabular}{|c|c|c|c|c|c|c|c|}
\hline \multirow{3}{*}{$\begin{array}{c}\text { Назва } \\
\text { деззасобу }\end{array}$} & \multirow{3}{*}{$\begin{array}{c}\text { Кон- } \\
\text { центрація } \\
\text { деззасобу, \% }\end{array}$} & \multicolumn{6}{|c|}{ Вид металу } \\
\hline & & \multicolumn{3}{|c|}{ алюміній } & \multicolumn{3}{|c|}{ нержавіюча сталь } \\
\hline & & $\begin{array}{c}\text { початкова } \\
\text { маса зразків, } \\
\Gamma \\
\end{array}$ & $\begin{array}{c}\text { маса зразків } \\
\text { через } 100 \text { год., } \\
\Gamma \\
\end{array}$ & $\begin{array}{c}\text { різниця маси } \\
\text { зразків до та після } \\
\text { досл., } \Delta \mathrm{m}, \Gamma \\
\end{array}$ & $\begin{array}{c}\text { початкова } \\
\text { маса зразків, } \\
\Gamma \\
\end{array}$ & $\begin{array}{c}\text { маса зразків } \\
\text { через } 100 \text { год., } \\
\Gamma \\
\end{array}$ & $\begin{array}{c}\text { різниця маси } \\
\text { зразків до та } \\
\text { після досл., } \Delta \mathrm{m}, \Gamma\end{array}$ \\
\hline \multirow{4}{*}{ ДезСан } & 0,25 & $\begin{array}{l}3,07234 \pm \\
0,00004\end{array}$ & $\begin{array}{l}3,07222 \pm \\
0,00006\end{array}$ & $\begin{array}{l}0,00012 \pm \\
0,00005\end{array}$ & $\begin{array}{l}3,06929 \pm \\
0,00012\end{array}$ & $\begin{array}{l}3,06926 \pm \\
0,00010\end{array}$ & $\begin{array}{l}0,00003 \pm \\
0,00002\end{array}$ \\
\hline & 0,5 & $\begin{array}{l}3,04267 \pm \\
0,00003\end{array}$ & $\begin{array}{l}3,04253 \pm \\
0,00008\end{array}$ & $\begin{array}{l}0,00014 \pm \\
0,00004\end{array}$ & $\begin{array}{l}3,07142 \pm \\
0,00018\end{array}$ & $\begin{array}{l}3,07134 \pm \\
0,00082\end{array}$ & $\begin{array}{l}0,00008 \pm \\
0,00004\end{array}$ \\
\hline & 1,0 & $\begin{array}{l}3,05536 \pm \\
0,00005\end{array}$ & $\begin{array}{l}3,05518 \pm \\
0,00003\end{array}$ & $\begin{array}{l}0,00018 \pm \\
0,00003\end{array}$ & $\begin{array}{l}3,07235 \pm \\
0,00015\end{array}$ & $\begin{array}{l}3,07221 \pm \\
0,00012\end{array}$ & $0,00014 \pm$ \\
\hline & 1,5 & $\begin{array}{l}3,05465 \pm \\
0,00003\end{array}$ & $\begin{array}{l}3,05443 \pm \\
0,00004\end{array}$ & $\begin{array}{l}0,00022 \pm \\
0,00002\end{array}$ & $\begin{array}{l}3,04523 \pm \\
0,00017\end{array}$ & $\begin{array}{l}3,04506 \pm \\
0,00013\end{array}$ & $\begin{array}{l}0,00017 \pm \\
0,00003\end{array}$ \\
\hline $\begin{array}{l}\text { Натр } \\
\text { їдкий } \\
(\mathrm{NaOH})\end{array}$ & 1,5 & $\begin{array}{l}4,65632 \pm \\
0,00254\end{array}$ & $\begin{array}{l}2,0058 \pm \\
0,00186\end{array}$ & $\begin{array}{l}2,65052 \pm \\
0,00124\end{array}$ & $\begin{array}{l}3,05074 \pm \\
0,00456\end{array}$ & $\begin{array}{l}3,05039 \pm \\
0,00234\end{array}$ & $\begin{array}{l}0,00035 \pm \\
0,00254\end{array}$ \\
\hline
\end{tabular}

Таблиця 2

Ступінь корозійної дії біоциду “ДезСан” на оцинковану сталь $(\mathrm{M} \pm \mathrm{m}) \mathrm{n}=10$

\begin{tabular}{|c|c|c|c|c|}
\hline \multirow{3}{*}{$\begin{array}{c}\text { Назва } \\
\text { деззасобу }\end{array}$} & \multirow{3}{*}{$\begin{array}{l}\text { Концентрація } \\
\text { деззасобу, \% }\end{array}$} & \multicolumn{3}{|c|}{ Вид металу } \\
\hline & & \multicolumn{3}{|c|}{ оцинкована сталь } \\
\hline & & початкова маса зразків, г & маса зразків через 100 год., г & $\begin{array}{c}\text { різниця маси зразків до та } \\
\text { після досл., } \Delta \mathrm{m}, \Gamma\end{array}$ \\
\hline \multirow{4}{*}{ ДезСан } & 0,25 & $3,06358 \pm 0,00033$ & $3,06320 \pm 0,00024$ & $0,00038 \pm 0,00007$ \\
\hline & 0,5 & $3,09367 \pm 0,00053$ & $3,09324 \pm 0,00044$ & $0,00043 \pm 0,00023$ \\
\hline & 1,0 & $3,08369 \pm 0,00029$ & $3,08317 \pm 0,00025$ & $0,00052 \pm 0,00026$ \\
\hline & 1,5 & $3,03458 \pm 0,00034$ & $3,03397 \pm 0,00021$ & $0,00061 \pm 0,00041$ \\
\hline $\begin{array}{l}\text { Натр ӥдкий } \\
(\mathrm{NaOH})\end{array}$ & 1,5 & $4,93865 \pm 0,00136$ & $2,33694 \pm 0,00115$ & $2,60171 \pm 0,00101$ \\
\hline
\end{tabular}

Корозійну активність біоциду “ДезСан” визначали за втратою маси зразків, поділивши різницю маси зразків до та після застосування препарату $(\Delta m)$ на площу зразків $(s)$. Зазначені дані наведені в таблиці 3.
Аналіз отриманих результатів досліджень, наведених в таблицях 1-3 вказує на те, що біоцид "ДезСан" в усіх взятих для досліду концентраціях $(0,25-1,5 \%)$ чинить незначну корозійну дію на алюміній, нержа- 
віючу та оцинковану сталь, в порівнянні з еталоном (1,5\% розчином $\mathrm{NaOH})$.

Біоцид “ДезСан” при потраплянні на зразки металів не викликає їх деформацію.

Підсумовуюче все вище згадане, можна стверджувати що біоцид “ДезСан” має незначну корозійну активність на алюміній, нержавіючу та оцинковану сталь, в порівнянні з 1,5\% $\mathrm{NaOH}$, тому його можна використовувати для дезінфекції об'єктів птахівництва.

В подальшому були проведені дослідження щодо визначення піноутворюючих властивостей розчинів засобу “ДезСан”. Отримані результати досліджень наведено в табл. 4.

\section{Таблиця 3}

Зменшення маси зразків металів (К) через 100 год. під дією дезінфікуючих засобів

\begin{tabular}{|c|c|c|c|c|c|c|c|}
\hline \multirow{4}{*}{ Назва деззасобу } & \multirow{4}{*}{$\begin{array}{l}\text { Концентрація } \\
\text { деззасобу, \% }\end{array}$} & \multicolumn{6}{|c|}{ Вид металу } \\
\hline & & \multicolumn{2}{|c|}{ алюміній } & \multirow{2}{*}{\multicolumn{2}{|c|}{$\begin{array}{l}\text { нержавіюча сталь } \\
\mathrm{K}=\Delta \mathrm{m} / \mathrm{s}^{*}, \Gamma / \mathrm{m}^{2}\end{array}$}} & \multicolumn{2}{|c|}{ оцинкована сталь } \\
\hline & & & & & & & \\
\hline & & $\Gamma / \mathrm{M}^{2}$ & $\%$ & $\Gamma / \mathrm{M}^{2}$ & $\%$ & $\Gamma / \mathrm{M}^{2}$ & $\%$ \\
\hline \multirow{4}{*}{ ДезСан } & 0,25 & 0,133 & 0,0039 & 0,0333 & 0,0001 & 0,4222 & 0,0124 \\
\hline & 0,5 & 0,155 & 0,0046 & 0,0888 & 0,0026 & 0,4777 & 0,0126 \\
\hline & 1,0 & 0,200 & 0,0059 & 0,1555 & 0,0045 & 0,5777 & 0,0168 \\
\hline & 1,5 & 0,244 & 0,0072 & 0,1888 & 0,0056 & 0,6777 & 0,0201 \\
\hline Натр їдкий (NaOH) & 1,5 & 2945,022 & 59,62 & 0,3888 & 0,011 & 2890,788 & 52,680 \\
\hline
\end{tabular}

Примітки: $1 .{ }^{*} \Delta \mathrm{m}$ - різниця маси зразків до та після досліджень; 2. $\mathrm{s}$ - площа зразка, ${ }^{2}$

\section{Таблиця 4}

Піноутворююча здатність розчинів біоциду “ДезСан”, $(\mathrm{M} \pm \mathrm{m}), \mathrm{n}=10$

\begin{tabular}{ccc}
\hline Концентрація розчину, \% & Піноутворююча здатність, $\%$ & Стійкість піни \\
\hline 0,25 & $13,1 \pm 0,78$ & $0,08 \pm 0,003$ \\
0,5 & $17,3 \pm 0,52$ & $0,11 \pm 0,004$ \\
1,0 & $24,3 \pm 0,71$ & $0,13 \pm 0,004$ \\
1,5 & $26,3 \pm 0,78$ & $0,15 \pm 0,005$ \\
2,0 & $32,6 \pm 0,92$ & $0,16 \pm 0,004$ \\
2,5 & $37,3 \pm 1,03$ & $0,19 \pm 0,007$ \\
\hline
\end{tabular}

Аналізуючи таблицю 4, можемо сказати, що “ДезСан” в різних концентраціях має піноутворюючу властивість від 13,1 до 37,3\%, яка підвищувалася прямо пропорційно до збільшення концентрації деззасобу. Піноутворююча здатність “Дезсану” не перевищувала $40 \%$, а стійкість піни за цих концентрацій змінювалась в межах 0,08-0,19, що сприяє успішному застосуванню даного біоциду в птахівничій галузі.

\section{Висновки}

Таким чином, біоцид “ДезСан” має низькі корозійні властивості щодо алюмінію, неіржавіючої сталі та оцинкованої сталі в порівнянні 3 еталоном $(1,5 \%$ розчином $\mathrm{NaOH})$. Біоцид “ДезСан” при потраплянні на зразки металів не викликає їх деформацію. Піноутворююча здатність була не більше $40 \%$, а стійкість піни була до 0,19. Дані показники дозволяють широко використовувати біоцид “ДезСан” в птахівничій галу3 i.

Перспективи подальших досліджень. В подальшому планується провести дослідження токсичності біоциду “ДезСан” та його віруліцидних і бактерицидних властивостей.

\section{References}

Benson, E., Malone, G.W., Alphin, R.L. et al. (2007). Foam-based mass emergency depopulation of floor- reared meattype poultry operations. Poultry Sci., 86(2), 219-224. doi: 10.1093/ps/86.2.219.

Berezovskyi, A.V., Fotina, T.I., \& Fotina, H.A. (2007). Zastosuvannia novitnikh zasobiv i metodiv sanatsii obiektiv ptakhivnytstva ta kontrol yikh efektyvnosti: [metodychni rekomendatsii]. Kyiv (in Ukrainian).

Instruktsiia z provedennia sanitarnoi obrobky dezinfektsii, dezinsektsii ta deratyzatsii obiektiv ptakhiv-nytstva (2016). Resource access mode: http://search.ligazakon.ua/1_doc2.nsf/link1/RE14080.h tml (in Ukrainian).

Metodika opredelenija i ocenki korrozionnoj aktivnosti mojushhih i dezinficirujushhih preparatov. Utv. GUV.MSH. SSSR. 20.06.74. M.: Gosstandart SSSR. Izdatel'stvo standartov (in Russian).

Nechyporenko, O.L., Berezovskyy, A.V., Fotina, T.I., Petrov, R.V., \& Fotin, A.I. (2018). Efficiency of complex disinfecting measures in the conditions of poultry farming. Scientific Messenger of Lviv National University of Veterinary Medicine and Biotechnologies, 20(92), 165-168. doi: 10.32718 /nvlvet 9234 .

Palii, A.P., \& Zavhorodnii, A.I. (2011). Suchasni problemy dezinfektolohii ta shliakhy yikh vyrishennia. Nauk. visn. Luhan. nats. ahrar. un-tu. Ser. Veterynarni nauky, 31, 110-113 (in Ukrainian).

Tishyn, O.L., Kopijchuk, G.T., Khomiak, R.V., Khyrivskyy, O.V., \& Danko, M.M. (2017). Bactericidal and disinfective properties of disinfectant 
"Alkisept-100". Scientific Messenger LNUVMBT named after S.Z. Gzhytskyj, 19(73), 61-65. doi: 10.15421/nvlvet7313.

Tishyn, O.L., Kopijchuk, G.T., Khomiak, R.V., Khyrivskyy, O.V., \& Orynchak, T.V. (2017). Bactericidal and disinfective properties of disinfectant
“Arquadez-plus". Scientific Messenger LNUVMB, 19(78), 68-73. doi: 10.15421/nvlvet7814.

Zavhorodnii, A.I., Stehnii, B.T., \& Palii, A.P. (2013). Naukovi ta praktychni aspekty dezinfektsii u veterynarnii medytsyni. Kharkiv (in Ukrainian). 